\title{
USE OF BIODIESEL WASTE FOR EFFICIENT PRODUCTION OF CELLULOSIC MEMBRANES: A “GREEN” PROPOSAL FOR FILTER PREPARATION
}

\author{
LUDHIMILLA S. G. LINS, ${ }^{*}$ WAGNER E. SILVA, ${ }^{*}$ MÔNICA F. BELIAN* and \\ GLÍCIA M. T. CALAZANS ${ }^{* *}$ \\ "Department of Chemistry, Federal Rural University of Pernambuco, 52.171-900, Recife, Pernambuco, \\ Brazil \\ ${ }^{* *}$ Department of Antibiotics, Federal University of Pernambuco, 50.670-901, Recife, \\ Pernambuco, Brazil \\ Corresponding author: M. F. Belian,mfbelian@gmail.com
}

Received June 11, 2018

Production of bacterial cellulose (BC) by Gluconacetobacter xylinus was investigated in static culture form, using glycerol and biodiesel residue as the carbon sources and as raw material for technological purposes. The cellulosic material, obtained as a membrane, was characterized by spectroscopic techniques and its morphological aspects were investigated by scanning electron microscopy (SEM). In a medium containing 3\% (w/v) glycerol, the BC yield was higher than that from a glucose and mannitol based-medium. After 10 days, using a medium containing biodiesel residue, we obtained a satisfactory amount of BC. FT-IR spectra revealed that all the BC samples showed characteristic peaks, associated with the usual functional groups for this cellulosic material. These results suggested that glycerol could be a potential low-cost substrate for BC industrial scale production, based on its high performance and economic viability.

Keywords: biodiesel, glycerol waste, bacterial cellulose, filter

\section{INTRODUCTION}

The use of raw materials from renewable sources by the fuel industry is essential for the sustainable development of society, with biodiesel being currently considered the most promising renewable fuel. Biodiesel production has increased considerably in recent years, and in Brazil, it is estimated that gross production will reach over $3,000,000 \mathrm{~m}^{3}$ in 2014. Despite the efforts concentrated on production, the generation of co-products is a worrying factor. These coproducts make up $20 \%$ of the total production, with glycerol in the lead, making up $10 \%$ of the production. The excess crude glycerin produced in the biodiesel industry has led to a decline in the price of glycerin both on national and international markets, and it is considered a waste, rather than a profitable co-product.

Since 2004, in Brazil, through the National Program of Production and Use of Biodiesel (PNPB), the Federal Government has encouraged the production and use of biofuel as an alternative to fossil fuels, in order to promote the economic development of the country. A year later, public law $\mathrm{n}^{\mathrm{o}} 11,097$ determined that the introduction of biodiesel into the Brazilian energy matrix until 2008 should amount to at least $2 \%$ biodiesel to diesel (B2), with a 5\% addition (B5) after 2013. The forecasts for 2013, with the introduction of $\mathrm{B} 5$, reached a production of 250 thousand $t /$ year of glycerol. The scientific community is currently working to discover new applications of crude glycerol as a way of lowering the production cost of biodiesel.

Glycerol has been used in a range of products on the world market, especially in the production of filters, pharmaceuticals and foods, using approximately 30 and $15 \%$, respectively of all the produced glycerol. In this work, we propose ways to use glycerol waste for efficient production of cellulosic membranes to be applied as filters.

Bacterial cellulose (BC) is a kind of natural cellulose synthesized in abundance by aerobic 
gram-negative, acetic acid bacteria Acetobacter xylinum (re-classified as Gluconacetobacter xylinus or G. xylinus). BC is distinguished from wood source cellulose by its high purity, absence of lignin and hemicellulose, ${ }^{1}$ high degree of crystallinity and superior mechanical properties. ${ }^{2}$ This cellulosic material is characterized by a unique fibrillar nanostructure, which determines its distinguishing physical and mechanical properties, such as high porosity, high tensile strength, high water binding capacity and biocompatibility in clinical uses. ${ }^{3-5}$ These properties make it ideal for a broad range of technological and biomedical applications, including the production of filters, wound dressings, ${ }^{6}$ micro blood vessels, ${ }^{7}$ threedimensional scaffold material for tissue engineering of bone and cartilage, ${ }^{8,9}$ and tissue repair. ${ }^{10-12}$ The hydrophilic nature and native dimensions of $\mathrm{BC}$ allow the preparation of hydrophilic, biocompatible nanocomposites, with controlled mechanical properties for certain devices. ${ }^{13-16}$ The success of these applications depends on the ability of the industry to produce $\mathrm{BC}$ in an economically viable manner.

G. xylinus has the ability to produce cellulose, using linear terminal complexes, such as microfibrils, from a plethora of carbon sources (glucose, sucrose, fructose, mannitol, among others). ${ }^{17,18}$ A considerable problem in BC production is its low productivity, ${ }^{19}$ and its dependence on its culture, including cultivation method, composition of the growth medium, ${ }^{20}$ dissolved oxygen, ${ }^{21}$ temperature and $\mathrm{pH}$ of the growth medium..$^{22}$ The cost of the raw materials, especially carbon sources, determines how expensive the microbial fermentation processes will be. Thus, the use of a cheap carbon source is important for industrial production of biotechnological products. This means that more studies on BC production by G. xylinus strains must be carried out, to solve the negative aspects in the production of this material. ${ }^{23-25}$

The aim of the current work was to study the performance of glycerol waste as carbon source for BC production using G. xylinus ATCC 23769, with the objective of an efficient green production of membranes, through depletion of the carbon source in the medium. It should be noted that no previous study has used a raw residue, that is, without any previous treatment for the carbon source. Another aspect is that, for the present study, there was no supplementation of the carbon source to obtain cellulose membranes. Various aspects of the structure and physical and chemical properties of cellulose microfibrils were investigated by scanning electronic microscopy, electron dispersive scanning, infrared spectroscopy, thermogravimetric analysis and Xray diffractometry. Taking into account the recognized potential of the G. xylinus strain to produce bacterial cellulose using glycerol as carbon source, this study assessed the feasibility and the potential of obtaining the biopolymer using four different concentrations of glycerol waste (industrial), and compared the results with glycerol for analysis.

\section{EXPERIMENTAL}

\section{Chemicals and measurements}

The starting chemicals were D-mannitol $\geq 99 \%$, glycerol $99.5 \%$, yeast extract, $\mathrm{Na}_{2} \mathrm{HPO}_{4} \cdot 12 \mathrm{H}_{2} \mathrm{O}$ and succinic acid $\geq 99 \%$ (Aldrich). The crude glycerol sample was acquired from the Experimental Biodiesel Plant at Caetés in Pernambuco.

The characteristic functional groups of bacterial cellulose, produced by G. xylinum, were analyzed by infrared spectroscopy. The vibrational spectra of the biopolymer obtained for different culture media were recorded for samples prepared by the $\mathrm{KBr}$ pellet method. The FT-IR spectra were generated by a Bruker Fourier transform spectrophotometer, model IF66, covering the region of $4000-500 \mathrm{~cm}^{-1}$, with a spectral resolution of $4 \mathrm{~cm}^{-1}$. Thermogravimetric curves (matrix characterization) were obtained in a TGA $50 / 50 \mathrm{H}$ Shimadzu under $\mathrm{N}_{2}$ atmosphere and a heating rate of $10{ }^{\circ} \mathrm{C} \mathrm{min}^{-1}$. The differential scanning calorimetry analyses were performed under $\mathrm{N}_{2}$ atmosphere $(50 \mathrm{~mL}$ $\min ^{-1}$ ) in a Shimadzu DSC-50WS.

$\mathrm{X}$-ray diffractograms were obtained in an X-ray diffractometer, Bruker D8 Advance Davinci model, with $\mathrm{Cu}-\mathrm{k} \alpha$ radiation $(\lambda=1.54 \AA)$, at a rate of $0.03^{\circ} \mathrm{s}^{-1}$, and scanning from 5 to $60^{\circ}$. The crystallinity index (Eq. 1) was calculated according to the intensity of the peak (200), represented in the formula by $\mathrm{I}_{(200)}$, and the minimum intensity between (200) and (110) represented by $I_{(a m)}$, which corresponds only to the amorphous region and is located at approximately $18^{\circ}$ in $2 \theta^{26}$

$\left.\mathrm{IC}=\left(\mathrm{I}_{(200)}-\mathrm{I}_{(\mathrm{am})}\right) / \mathrm{I}_{(200)}\right)$

\section{Microorganism and culture conditions}

Gluconacetobacter xylinus ATCC 23769 was grown and maintained in a mannitol medium, composed of $2.5 \%(\mathrm{w} / \mathrm{v})$ D-mannitol, $0.5 \%(\mathrm{w} / \mathrm{v})$ yeast extract, $0.3 \%$ (w/v) bacteriological peptone, all dissolved in distilled water (adjusted to $\mathrm{pH}$ 6.5). Three different carbon sources (mannitol, glucose and glycerol), each one distributed in 3 different culture media, were evaluated as to their performance in cellulose production. The (i) Hestrin and Schramm 
(HS) and (ii) glycerol media had the following composition: (i) (Hestrin and Schramm, 1954) (20 g L ${ }^{1}$ glucose, $5 \mathrm{~g} \mathrm{~L}^{-1}$ yeast extract, $5 \mathrm{~g} \mathrm{~L}^{-1}$ peptone, $3.4 \mathrm{~g} \mathrm{~L}^{-}$ ${ }^{1} \mathrm{Na}_{2} \mathrm{HPO}_{4}, 1.15 \mathrm{~g} \mathrm{~L}^{-1}$ citric acid); (ii) (30 $\mathrm{g} \mathrm{L}^{-1}$ glycerol, $16 \mathrm{~g} \mathrm{~L}^{-1}$ yeast extract, $4 \mathrm{~g} \mathrm{~L} \mathrm{~L}^{-1}$ $\mathrm{Na}_{2} \mathrm{HPO}_{4} \cdot 12 \mathrm{H}_{2} \mathrm{O}$ and succinic acid $3.5 \mathrm{~g} \mathrm{~L}^{-1}$ ). The strain was inoculated into $50 \mathrm{~mL}$ of each medium, distributed in $200 \mathrm{~mL}$ borosilicate glass bottles, sealed with cotton (sterile system) and incubated for 2 days under static conditions at $30^{\circ} \mathrm{C}$. Then, from these cell suspensions (1.4-3.0 x $10^{7}$ cells $\left./ \mathrm{mL}\right), 5 \mathrm{~mL}$ aliquots were transferred to their respective culture media (50 $\mathrm{mL})$ contained in other borosilicate glass bottles (200 $\mathrm{mL})$. For all the culture media, the $\mathrm{pH}$ values $(4,5$ and 6 ) were adjusted with acetic acid, at the same time as the empirical model building, i.e. the acetic acid, contributed to elucidating the $\mathrm{pH}$ influence on $\mathrm{BC}$ production.

The results of the initial tests demonstrated the potential of the $G$. xylinus strain in the bacterial cellulose production in the medium containing glycerol as a carbon source, followed by an assessment of the viability and potential of obtaining the biopolymer in different concentrations of glycerol waste compared with glycerol PA.

Amounts of $400 \mathrm{~mL}$ of each medium were prepared, containing $16.0 \mathrm{~g} \mathrm{~L}^{-1}$ of yeast extract, $1.6 \mathrm{~g}$ $\mathrm{L}^{-1}$ of $\mathrm{Na}_{2} \mathrm{HPO}_{4}$ and $3.5 \mathrm{~g} \mathrm{~L}^{-1}$ of succinic acid, at $\mathrm{pH}$ 5.0. The variables, in this case, were the source of glycerol and the amount used (Table 1).

The crude waste of glycerin was filtered in two steps, a pre-filtering in simple paper and the second using quantitative paper. When the $\mathrm{pH}$ had been verified and adjusted to the desired range, the waste was distributed $(90 \mathrm{~mL})$ in four flasks with $500 \mathrm{~mL}$ of the buffered medium. All the media were sterilized by autoclaving at $121{ }^{\circ} \mathrm{C}$ for 15 minutes.

At the times $T_{i}$ and $T_{f}(0,504 h$, respectively), samples of $10 \mathrm{~mL}$ were collected and centrifuged for $15 \mathrm{~min}$ at $16,800 \mathrm{G}$. The supernatants were removed and frozen for analysis of the glycerol concentration in the samples. At the end of 7 days of culture, the membranes were washed and purified.
The carbon source concentration, throughout the fermentation, was determined by high-performance liquid chromatography (HPLC). Supernatant samples were withdrawn and filtered with a $0.22 \mu \mathrm{m}$ filter. The carbon sources were analyzed by gel chromatography and exclusion molecular weight method - AMINEX HPX-87H®-column (silica based column), at $60{ }^{\circ} \mathrm{C}$, flow rate of $0.6 \mathrm{~mL} \mathrm{~min}^{-1}$, using sulfuric acid $(5 \mathrm{mmol}$ $\mathrm{L}^{-1}$ ) as eluent. The detector used was based on the refractive index.

\section{Purification of the bacterial cellulose membranes}

The BC samples were withdrawn from the culture medium with a sieve and gauze, and deposited in a Petri dish with distilled water, where they remained for 10 minutes. This procedure was repeated 7 times to remove the cellular debris and culture medium from the bacterial cellulose membrane. The water was then removed and the $\mathrm{BC}$ membrane was immersed in a solution of $\mathrm{NaOH}\left(0.1 \mathrm{~mol} \mathrm{~L}^{-1}\right)$ for 30 minutes in a water bath at $80{ }^{\circ} \mathrm{C}$. After the elapsed time, the $\mathrm{BC}$ membrane was washed with ultrapure water at $50{ }^{\circ} \mathrm{C}$. This procedure was repeated until the washing water had $\mathrm{pH}=7$.

To evaluate the process yields, the bacterial cellulose membranes were weighed and placed in an oven at $80^{\circ} \mathrm{C}$ for drying to constant weight.

From the dry weight values, the yields were calculated correlating the data of the carbon source consumption with the dry weight of the bacterial cellulose membrane obtained; (Yp/s) was calculated for the biomass production by substrate consumption (Eq. 2).

$Y_{P / S}=\frac{P_{f}}{S_{i}-S_{f}}$

where $P_{f}=$ final product/BC membrane; $S_{i}=$ carbon source initial; $S_{f}=$ carbon source final. Then, from the yield results, it was possible to calculate the productivity process $(P)$ (Eq. 3):

$$
P=\frac{Y_{P / S}}{t_{(\text {dias })}} ; \text { expressed in g/g.day }{ }^{-1}
$$

Table 1

Composition of culture media

\begin{tabular}{lcc}
\hline Culture medium & Carbon source & Concentration $\left(\mathrm{g} \mathrm{L}^{-1}\right)$ \\
\hline Glycerol medium & Glycerol & 30.0 \\
Waste medium 30 & Crude waste & 30.0 \\
Waste medium 37.5 & Crude waste & 37.5 \\
Waste medium 50 & Crude waste & 50.0 \\
Waste medium 60 & Crude waste & 60.0 \\
\hline
\end{tabular}



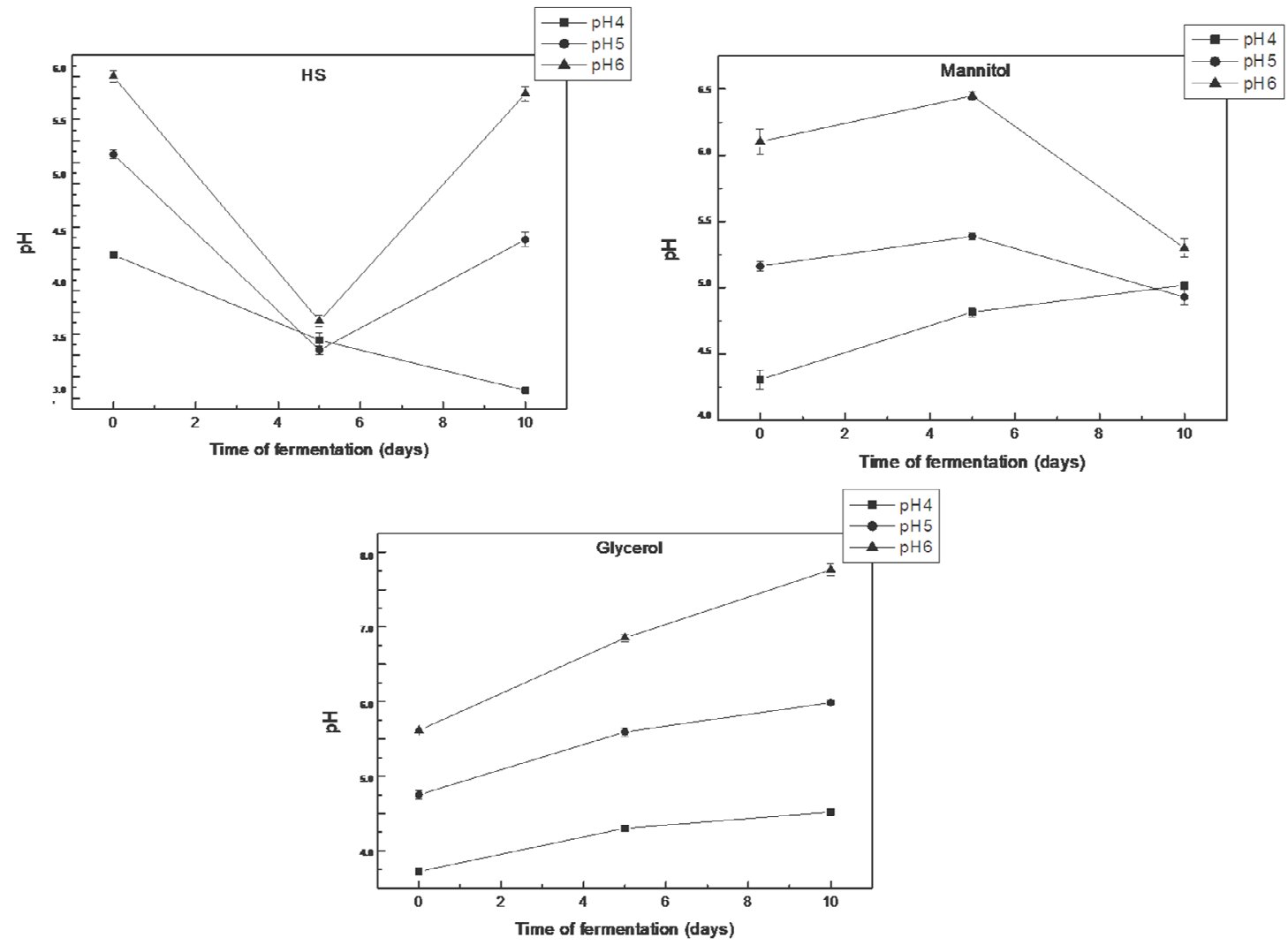

Figure 1: Evolution of $\mathrm{pH}$ during $\mathrm{BC}$ production in (A) HS medium, (B) mannitol medium, and (C) glycerol medium

\section{RESULTS AND DISCUSSION}

Bacterial cellulose membrane production: yield, production and characterization

The $\mathrm{pH}$ conditions observed in the culture media of fermentations, with $\mathrm{pH}$ adjusted to 4,5 and 6 obtained for the samples, throughout the experiment, are presented in Figures 1 and 2.

Although the results obtained for the HS and glycerol media were similar, at their $\mathrm{pH}=5.0$ and 6.0 , for the production of bacterial cellulose, the correlation of the performance of the production with respect to the substrate used was not possible. The $\mathrm{pH}$ in the mannitol and glycerol medium was stabilized, showing the same tendency, but with very different values in comparison to the two cases on average (considering the logarithmic scale). The $\mathrm{pH}$ during the fermentation decreased in the HS medium, being justified by the formation of gluconic acid, which was a product of glucose metabolism by G. xylinum. According to Keshk and Sameshima, ${ }^{20}$ this production of gluconic acid is responsible for the inefficiency of bacterial cellulose production, which prevents the development of a fermentation system on a large scale. For other cases reported in the literature and results obtained in HPLC, no presence of gluconic acid was observed during fermentation, in the glycerol and mannitol media, and the $\mathrm{pH}$ was kept stable during the process (Fig. 1).

Masaoka et al. ${ }^{27}$ included various carbon sources as monosaccharides, oligosaccharides, alcohols and organic acids, aiming to maximize the production of bacterial cellulose by Gluconacetobacter xylinum. In the present study, we evaluated the ability of the bacteria to metabolize three sources of carbon, highlighting the effect of these substrates on cellulose production. The bacterial cellulose production efficiency using G. xylinum consists in the ability of the microorganism to synthesize glucose from different carbon sources, followed by glucose chain polymerization $\beta(1 \rightarrow 4)$ glycan, which is responsible for the formation of cellulose fibers.

Among the carbon sources used by G. xylinum for bacterial cellulose production, the glycerol medium showed better yields of $0.046 \mathrm{~g}$ of $\mathrm{BC}$ for each $\mathrm{g}$ of glycerol used. In the mannitol medium, the yield of $0.022 \mathrm{~g} / \mathrm{g}$ was obtained; and in HS medium, there was $0.004 \mathrm{~g}$ of $\mathrm{BC}$ for each $\mathrm{g}$ of 
glucose. The glycerol and mannitol carbon sources produced, respectively, about 11.6 and 5.6 times more bacterial cellulose than the glucose. These values stand out in relation to the values found by Jonas and Farah, ${ }^{28}$ where the culture medium containing mannitol produced 3.8 times more BC than glucose. These results disagree with the results found by Jung et al. ${ }^{29}$ who did not consider glycerol as a good carbon source for bacterial cellulose production using $G$. xylinum.

The best performance, per liter, as described in the literature, was $15.3 \mathrm{~g} / \mathrm{L}$ for a 50 -hour process. These results refer to a "fresh membrane", however, which is treated with the same technique as used in this work, but underwent a process of vacuum drying in an oven for 8 hours. The yield results obtained in our work refer to a process of drying to constant weight that lasted around 26 to 28 hours.

Mikkelsen et $a l .{ }^{30}$ suggested the use of mannitol as a carbon source for fermentation experiments conducted with a drying time of up to 72 hours. If the experiments were conducted over $96 \mathrm{~h}$, the use of sucrose or glycerol for a higher yield would be indicated. Analyzing the data obtained in this study, the highest productivity recorded in the range of $240 \mathrm{~h}$ was that using glycerol, followed by mannitol and last through the medium of HS. BC production by $G$. xylinum strains in static cultures using glycerol as the carbon source has been investigated by several authors. ${ }^{14-16,27-31}$

In the mannitol and glycerol media, there was no change of $\mathrm{pH}$ during the fermentation process.

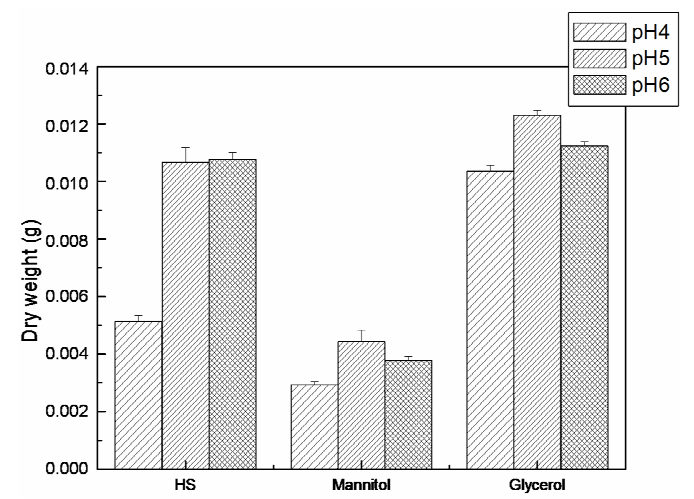

Figure 2: BC dry weight obtained from all culture media used in static form under different $\mathrm{pH}$ conditions
In all fermentations, the HS medium decreased the original $\mathrm{pH}$. The $\mathrm{pH}$ decline is not the only factor that determines the efficiency of $\mathrm{BC}$ production. The $\mathrm{pH}$ is established by the microorganism, however, during its growth in the culture medium, it should not be decreased since some metabolites of interest have a restricted dependence. This parameter can directly affect the nutrients' solubility and therefore the metabolism of the microorganism. A growing unfavorable $\mathrm{pH}$ may also contribute to increased energy expenditure by the cell to maintain intracellular $\mathrm{pH}$ at appropriate physiological values. Comparing the media used, with $\mathrm{pH}$ adjusted to 4.0, 5.0 and 6.0 with the media set to 5.0, the latter no doubt are those with the greater stability of $\mathrm{pH}$ and also those that best fostered the microorganisms' growth and a higher yield of polymer production (Fig. 4). This study agrees with the findings reported by Mikkelsen et al., ${ }^{30}$ who claims to have found a bacterial cellulose yield slightly higher than that reported by Ishihara et $a .^{32}$ due to the $\mathrm{pH} 5.0$ used in the culture medium. The medium with $\mathrm{pH}$ adjusted to 5.0 showed higher stability of $\mathrm{pH}$ and a higher growth of the microorganisms, and, as a consequence of this, an increase in bacterial cellulose production (Fig. 3).

G. xylinum ATCC 23769 in the HS culture medium consumed glucose, about three times more than glycerol and D-mannitol media, but this high consumption was not reflected in membrane productivity. Figure 4 shows the evolution of the substrate consumption and its influence on BC dry weight.

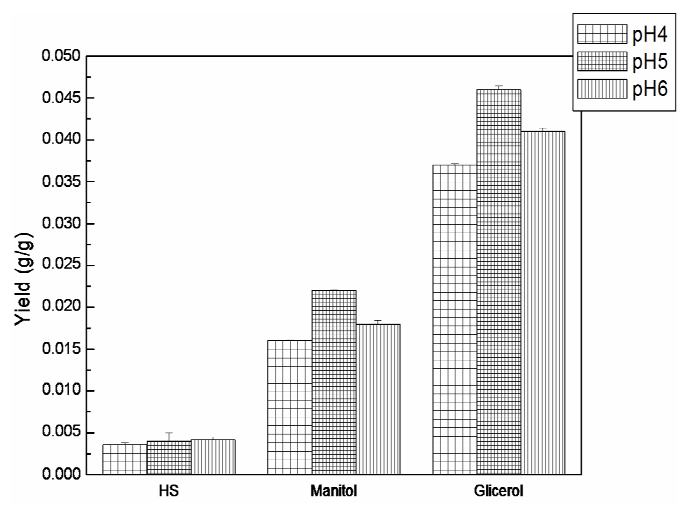

Figure 3: BC yields obtained from all culture media used in static form under different $\mathrm{pH}$ conditions 

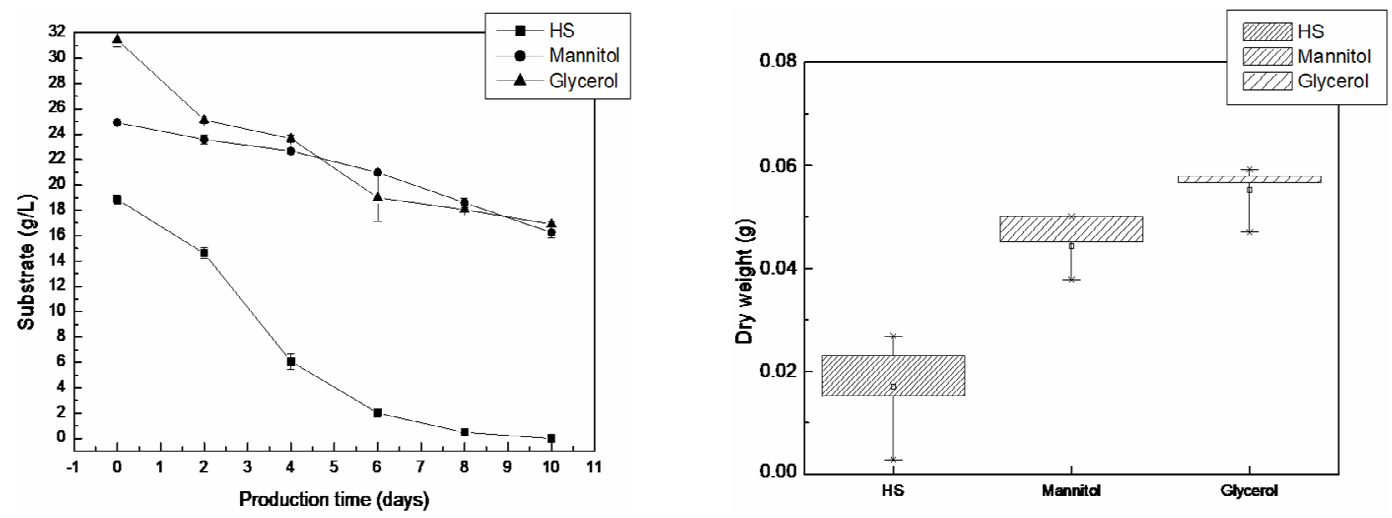

Figure 4: Chronological evolution of substrate consumption (left) and BC dry weight range of variation (right), for all culture media used in membrane production

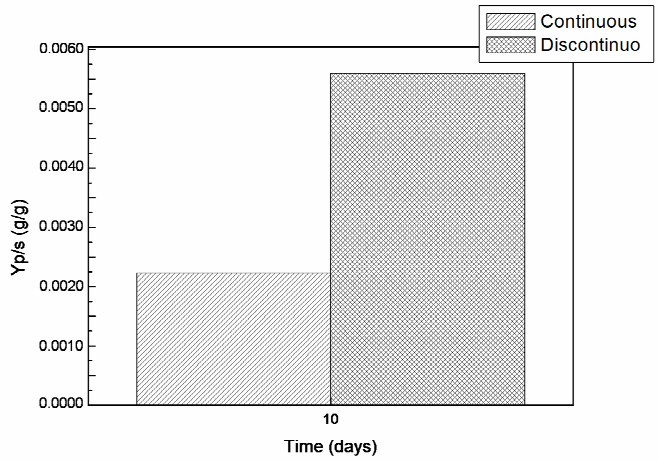

Figure 5: BC yields for continuous and discontinuous methods

A high $\mathrm{BC}$ productivity was obtained when glycerol was used as the carbon source, showing low consumption and high residual glycerol (after 10 days). Glycerol is a potentially useful substrate for BC production by Gluconacetobacter xylinum ATCC 23769 in a static culture. In the current work, for this bioprocess performed by $G$. xylinum under static conditions, we concluded that the optimum temperature for fermentation was $30{ }^{\circ} \mathrm{C}$ (data not shown) and $\mathrm{pH}$ adjusted to 5.0.

A variation in the $\mathrm{BC}$ production method was introduced, consisting in membrane removal at the end of the period established for its formation. In static cultivation, it was possible to produce bacterial cellulose at the end of four days. The membrane was removed with sterile tweezers, and the culture medium was reincubated, under the same conditions and without any component added to the medium. New cellulose membranes had been produced at the end of the fermentation process and consequently the air-liquid interface was removed again. The subsequent production of cellulose membrane was realized twice over 10 days and six times over 20 days of incubation. Figure 5 shows the results obtained, for the tests performed with membrane removal, after 10 days of incubation. The yield obtained from batch cultivation (removal of membrane) was calculated through the equation $Y_{P / S \text { (discontinuous) }}=P_{f} / S_{i}-S_{f}=$ $0.005598 \mathrm{~g} / \mathrm{g}, \quad$ or $2.5069 \quad\left(Y_{P / S} \quad\right.$ (continuous) $=$ 0.002233 ) times the continuous yield.

The presence of functional groups in the bacterial cellulose obtained by HS, mannitol and glycerol media was verified and analyzed through FTIR spectroscopy (Fig. 6(A)). The infrared spectrum of $\mathrm{BC}$ from the glycerol source revealed peaks similar to those of $\mathrm{BC}$ obtained from glucose and D-mannitol medium. The samples show a band around $2900 \mathrm{~cm}^{-1}$ corresponding to the $\mathrm{C}-\mathrm{H}$ stretching, typical in cellulose type I. The band at $1434 \mathrm{~cm}^{-1}$ corresponds to $\mathrm{C}-\mathrm{H}$ stretching and the band at $1060 \mathrm{~cm}^{-1}$ to C-O-C stretching. Another functional feature revealed by the IR spectrum is the presence of the $\mathrm{C}-\mathrm{O}$ and $\mathrm{C}-\mathrm{C}-\mathrm{O}$ bands, in the $1000-1200 \mathrm{~cm}^{-1}$ region, which confirms the existence of a structure associated with a carbohydrate, as does the band at $1060 \mathrm{~cm}^{-}$ 
${ }^{1}$. The fingerprint region (region below $1500 \mathrm{~cm}^{-1}$ ) was the focus of the structural characterization, since it involves a free region of the influence of vibrational hydroxyl groups $(\mathrm{OH})$ and its intraand intermolecular interactions (hydrogen bonds); and the possible presence of water.

The similarities between the infrared spectra of the bacterial cellulose obtained from different carbon sources were obtained from the relationship between the peaks in 1060,1434 and $1172 \mathrm{~cm}^{-1}: \mathrm{A}=1060 / 1434 ; \mathrm{B}=1060 / 1172 ; \mathrm{C}=$ 1434/1172. The results obtained are shown in Table 2 .

Analyzing the data obtained (Table 2), fluctuations can be seen in the calculated ratios for each sample, suggesting that the samples present minimal structural changes in the polymer (crystal domains, crystallinity index).

Figure 6 (B) shows the SEM micrograph of $\mathrm{BC}$ produced from the glycerol medium. In this part of our study, we verified the random distribution of microfibrils and elongated fibers, with microcrystalline pores of bacterial cellulose smaller than $1 \mu \mathrm{m}$. EDS analysis (data not shown) confirmed the presence of characteristic constituents of carbohydrate (carbon and oxygen), and the presence of sodium, on account of the washing process in which sodium hydroxide was used.

Figure 7 shows the X-ray diffraction pattern of the bacterial cellulose sample produced from glycerol residues.

According to the literature, the diffraction peaks that appear at $2 \theta=14.47,16.39$ and $22.73^{\circ}$ refer to the 110, 110 and 200 planes, which are characteristic of the cellulose. When comparing the information present in the literature with the results of the diffractogram, it is possible to observe that for the bacterial cellulose sample, the two peaks appear around $2 \theta=14.47$ and $22.73^{\circ}$. The crystallinity index $(\mathrm{CI})$, calculated by the Segal method, presents the value of $84.47 \%$, which is compatible with typical IC of celluloses produced from glycerol media.

\section{Glycerol residue tests}

Glycerol is a biodiesel fuel by-product that has been used in the production of microbial metabolites, as described by Bibel et al. ${ }^{30}$ The employment of glycerol waste as carbon source in the production of bacterial cellulose is an interesting alternative for the use of this byproduct.

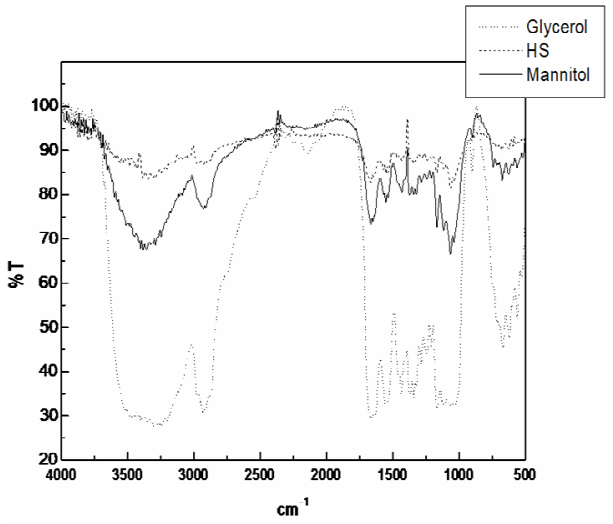

A)

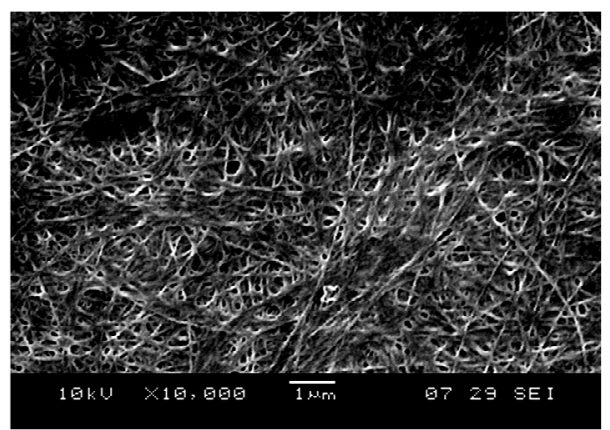

B)

Figure 6: (A) FT-IR for samples of BC produced in media of HS, mannitol and glycerol; and (B) SEM micrograph of $\mathrm{BC}$ produced in glycerol medium

Table 2

Relationship between peaks at 1060, 1434 and $1172 \mathrm{~cm}^{-1}: \mathrm{A}=1060 / 1434 ; \mathrm{B}=1060 / 1172 ; \mathrm{C}=1434 / 1172$; for all BC samples obtained from different culture media

\begin{tabular}{lccc}
\hline \multirow{2}{*}{ Culture medium } & \multicolumn{3}{c}{ Ratio } \\
\cline { 2 - 4 } & $\mathrm{A}$ & $\mathrm{B}$ & $\mathrm{C}$ \\
\hline HS & 0.9317 & 0.9585 & 1.0287 \\
Mannitol & 0.8345 & 0.9104 & 1.0909 \\
Glycerol & 0.9242 & 1.0114 & 1.0943 \\
\hline
\end{tabular}




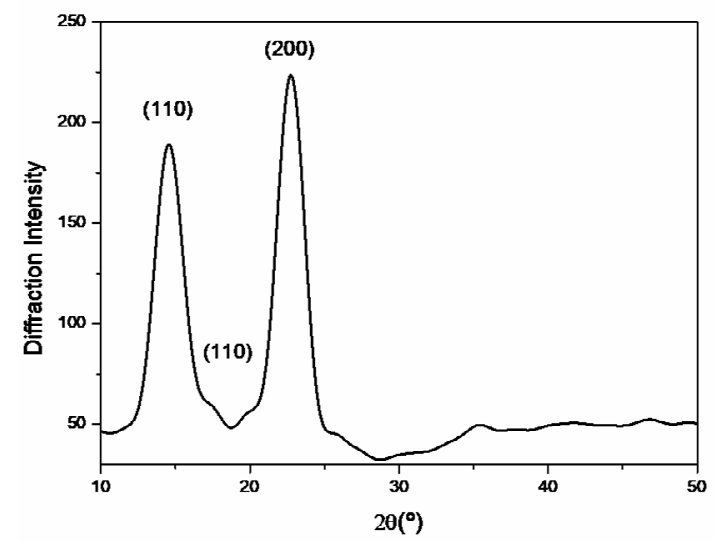

Figure 7: X-ray diffractogram of bacterial cellulose produced from glycerol waste

Table 3

Evaluation of bacterial cellulose production from glycerol and industrial waste containing glycerol

\begin{tabular}{lcccccccc}
\hline $\begin{array}{l}\text { Carbon } \\
\text { source } \\
\text { quantity }\end{array}$ & $\begin{array}{c}\text { gglycerol }_{\mathrm{i}} \\
\left(\mathrm{g} \mathrm{L}^{-1}\right)\end{array}$ & $\begin{array}{c}\mathrm{SD} \\
( \pm)\end{array}$ & $\begin{array}{c}\text { [glycerol }_{\mathrm{f}} \\
\left(\mathrm{g} \mathrm{L}^{-1}\right)\end{array}$ & $\begin{array}{c}\mathrm{SD} \\
( \pm)\end{array}$ & $\begin{array}{c}\text { Average } \\
\text { consumption }\end{array}$ & $\begin{array}{c}\text { Dry } \\
\text { weight } \\
\text { average } \\
(\mathrm{g})\end{array}$ & $\begin{array}{c}\mathrm{SD} \\
( \pm)\end{array}$ & $Y_{P / S}$ \\
\hline $\begin{array}{l}\text { Glycerol, } \\
30 \mathrm{~g} \mathrm{~L}^{-1}\end{array}$ & 29.14 & 0.59 & 23.99 & 0.01 & 5.14 & 0.109 & 0.0035 & 0.0210 \\
$\begin{array}{l}\text { Waste, } 30 \mathrm{~g} \\
\mathrm{~L}^{-1}\end{array}$ & 17.99 & 0.10 & 15.45 & 0.05 & 2.53 & 0.104 & 0.0033 & 0.0410 \\
$\begin{array}{l}\text { Waste, } 50 \mathrm{~g} \\
\mathrm{~L}^{-1}\end{array}$ & 30.00 & 0.02 & 27.88 & 0.12 & 12.11 & 0.165 & 0.0039 & 0.0778 \\
$\begin{array}{l}\text { Waste, } 60 \mathrm{~g} \\
\mathrm{~L}^{-1}\end{array}$ & 35.78 & 0.02 & 30.78 & 0.25 & 4.99 & 0.069 & 0.0032 & 0.0138 \\
\hline
\end{tabular}

$*[\text { glycerol }]_{\mathrm{i}}=$ initial glycerol concentration; $[\text { glycerol }]_{\mathrm{f}}=$ final glycerol concentration; $\mathrm{SD}=$ standard deviation

Glycerol waste is composed basically of glycerol $(92.8 \%)$, cellobiose $(4.3 \%)$, glucose $(1.8 \%)$ and xylose $(0.79 \%)$. The glycerol amount present in biodiesel residue was evaluated by high performance liquid chromatography (Table 3 ) in our study. The residues were obtained from the Experimental Biodiesel Plant in Caetés, Pernambuco.

Bacterial cellulose was produced from different concentrations of glycerol wastes. Table 3 shows that the glycerol concentration of $50 \mathrm{~g} \mathrm{~L}^{-1}$ in the waste sample is close to that used for the glycerol standard $\left(30 \mathrm{~g} \mathrm{~L} \mathrm{~L}^{-1}\right)$. The bacterial cellulose production in the medium containing biodiesel residue showed the highest yields, and when compared to the glycerol standard, seems to be a viable alternative to the use of this waste, with a lower cost-benefit ratio. The waste yield in $60 \mathrm{~g} \mathrm{~L}^{-1}$ was the least observed, due to the highest glycerol concentration in the sample. This trend, giving lower yields with increased concentration of the carbon source, is similar to that obtained when the glycerol standard is used.

\section{CONCLUSION}

BC production, under static conditions and using three different carbon sources, showed good yields. The results presented suggest that glycerol is a suitable raw material for BC production. The potential increase of biodiesel production currently leads to the need to discover ways to make use of this waste. This present work reveals that there are alternative ways to use this waste, as in the production of BC membranes, in order to achieve added value products from metabolic compounds.

ACKNOWLEDGEMENTS: The authors are grateful to $\mathrm{CNPq}$ and FACEPE for financial support. 


\section{REFERENCES}

1 D. Klemm, D. Schumann, F. Kramer, N. Hebler, M. Hornung et al., Adv. Polym. Sci., 205, 49 (2006), https://doi.org/10.1007/12_097

2 G. Guhados, W. K. Wan and J. L. Hutter, Langmuir, 21, 6642 (2005), https://doi.org/10.1021/la0504311

3 F. Hong and K. Qiu, Carbohyd. Polym., 72, 545 (2008), https://doi.org/10.1016/j.carbpol.2007.09.015

4 M. Iguchi, S. Yamanaka and A. Budhiono, J. Mater. Sci., 35, 261 (2000), https://doi.org/10.1023/A:1004775229149

5 R. Salihu, C. Y. Foong, S. I. Abd Razak, M. R. A. Kadir, A. H. M. Yusof et al., Cellulose Chem. Technol., $\quad \mathbf{5 3}, \quad 1 \quad$ (2019), http://www.cellulosechemtechnol.ro/pdf/CCT12(2019)/p.1-13.pdf

${ }^{6}$ W. K. Czaja, A. Krystynowicz, S. Bielecki and R. M. Brown Jr., Biomaterials, 27, 145 (2006), https://doi.org/10.1016/j.biomaterials.2005.07.035

7 D. Klemm, D. Schumann and U. Udhardt, Prog. Polym. Sci., 26, $1561 \quad$ (2001), https://doi.org/10.1016/S0079-6700(01)00021-1

8 H. Jiang, Y. Wang, S. Jia, Y. Huang, F. He et al., Key Eng. Mat., 330-332, 923 (2007), https://doi.org/10.4028/www.scientific.net/KEM.330332.923

9 A. Svensson, E. Nicklasson, P. Gatenholm, M. Brittberg, T. Harrah et al., Biomaterials, 26, 419 (2005), https://doi.org/10.1016/j.biomaterials.2004.02.049

10 P. J. Christner, C. M. Artlett, R. F. Conway and S. A. Jimenez, Arthritis Rheum., 43, 2598 (2000), https://doi.org/10.1002/1529-

0131(200011)43:11<2598::AID-ANR30>3.0.CO;2-8

11 L. R. Mello, L. T. Feltrin, P. T. Fontes Neto and F. A. Ferraz, J. Neurosurg., 86, 143 (1997), https://doi.org/10.3171/jns.1997.86.1.0143

12 A. Suehiro, S. Kanemaru, H. Umeda, Y. Amano, K. Omori et al., Tissue Eng., 13, 1642 (2007)

13 L. E. Million, G. Guhados and W. K. Wan, J. Biom. Mater. Res. Part B-Appl. Biom., 86B, 444 (2008), https://doi.org/10.1002/jbm.b.30535

14 R. F. Dórame-Miranda, N. Gámez-Meza, L. Á. Medina-Juárez, J. M. Ezquerra-Brauer, M. OvandoMartínez et al., Carbohyd. Polym., 207, 91 (2019), https://doi.org/10.1016/j.carbpol.2018.11.067

15 G. Gayathri and G. Srinikethan, Biocatal. Agric. Biotechnol., $\quad$ 16, $326 \quad$ (2018), https://doi.org/10.1016/j.bcab.2018.08.024

16 B. Sun, Q. Zi, C. Chen, H. Zhang, Y. Gu et al., Cellulose Chem. Technol., 52, 795 (2018),
http://www.cellulosechemtechnol.ro/pdf/CCT910(2018)/p.795-801.pdf

17 F. Mohammadkazemi, M. Azin and A. Ashori, Carbohyd. Polym., 117, 518 (2015), https://doi.org/10.1016/j.carbpol.2014.10.008

18 R. Singh, A. Mathur, N. Goswami and G. Mathur, e-Polymers, 16, 331 https://doi.org/10.1515/epoly-2016-0047

19 P. Ross, R. Mayer, D. Winehouse, D. Amikan, Y. Huggirat et al., J. Biol. Chem., 265, 18933 (1990), http://www.jbc.org/content/265/31/18933.full.pdf

20 S. M. A. S. Keshk and K. Sameshima, African J. Biotechnol., 4, $478 \quad$ (2005). URL: http://www.academicjournals.org/app/webroot/article/a rticle1380032315_Keshk\%20and\%20Sameshima.pdf

21 T. Kouda, T. Naritomi, H. Yano and F. Yoshinaga, J. Ferm. Bioeng., $\quad \mathbf{8 5}, \quad 318 \quad$ (1998), https://doi.org/10.1016/S0922-338X(97)85682-6

22 N. Noro, Y. Sugano and M. Shoda, Appl. Microbiol. Biotechnol., 64, $199 \quad$ (2004), https://doi.org/10.1007/s00253-003-1457-6

23 P. Ross, R. Mayer and M. Benziman, Microbiol. Rev., 55, $\quad 35 \quad$ (1991), https://www.ncbi.nlm.nih.gov/pmc/articles/PMC37280 $0 /$

${ }^{24}$ H. J. Son, H. G. Kim, K. K. Kim, H. S. Kim, Y. G. Kim et al., Bioresour. Technol., 86, 215 (2003), https://doi.org/10.1016/S0960-8524(02)00176-1

${ }_{25}$ Y. H. Jin, T. Lee, J. R. Kim, Y.-E. Choi and C. Park, J. Ind. Eng. Chem., 75, 158 (2019), https://doi.org/10.1016/j.jiec.2019.03.017

26 E. H. Qua, P. R. Hornsby, H. S. S. Sharma and G. Lyons, Int. J. Mat. Sci., 46, 6029 (2011), https://doi.org/10.1007/s10853-011-5565-x

27 S. Masaoka, T. Ohe and N. Sakota, J. Ferment. Bioeng., 75, 18 (1993), https://doi.org/10.1016/0922338X(93)90171-4

28 R. Jonas and L. F. Farah, Polym. Degrad. Stabil., 59, 101 (1998), https://doi.org/10.1016/S01413910(97)00197-3

29 H. Jung, J. H. Jeong, O. Lee, G. Park, K. Kim et al., Bioresour. Technol., 101, 3602 (2010), https://doi.org/10.1016/j.biortech.2009.12.111

30 B. M. Mikkelsen, G. A. Flanagan, M. J. Dykes and J. Gidley, J. Appl. Microbiol., 107, 576 (2009), https://doi.org/10.1111/j.1365-2672.2009.04226.x

${ }_{31}$ H. Bibel, A. P. Zeng, M. Menzel and W. D. Deckwer, Appl. Microbiol. Biotechnol., 50, 24 (1998), https://doi.org/10.1007/s002530051251

32 M. Ishihara, M. Matsunaga, N. Hayashi and V. Tišler, Enzyme Microb. Technol., 31, 986 (2002), https://doi.org/10.1016/S0141-0229(02)00215-6 